\title{
MORTGAGE IN THE RUSSIAN FEDERATION IN Q1 2013
}

\author{
G.Zadonsky
}

In January-February 2013, 83,925 MHL for the total amount of Rb132.94bn were extended which is $28.24 \%$ more in monetary terms than in January-February 2012. As of March 1, 2013, the outstanding debt on MHL amounted to Rb2.05 trillion having exceeded by $36.71 \%$ the respective debt as of March 1, 2012. In 2013, the overdue debt as compared to the outstanding debt on MHL in rubles kept decreasing and amounted to $1.45 \%$ as of March 1, while that on MHL in foreign currency was growing and amounted to $11.57 \%$ as of March 1, 2013. The debt on MHL with payment overdue for over 180 days was decreasing and as of March 1, 2013 amounted to 1.41\% of the total debt. The weighted average monthly rate on MHL in rubles kept growing and amounted to $12.8 \%$ in February.

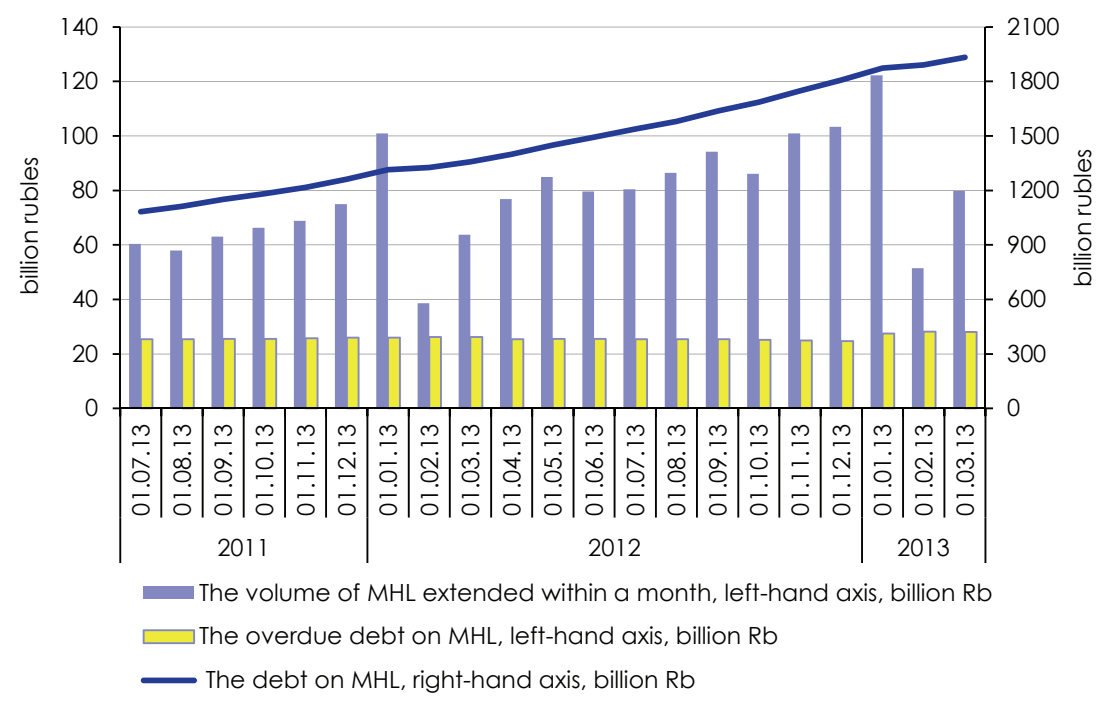

Source: the data of the Central Bank of the Russian Federation. Fig. 1. Dynamics of MHL and debt on MHL in rubles

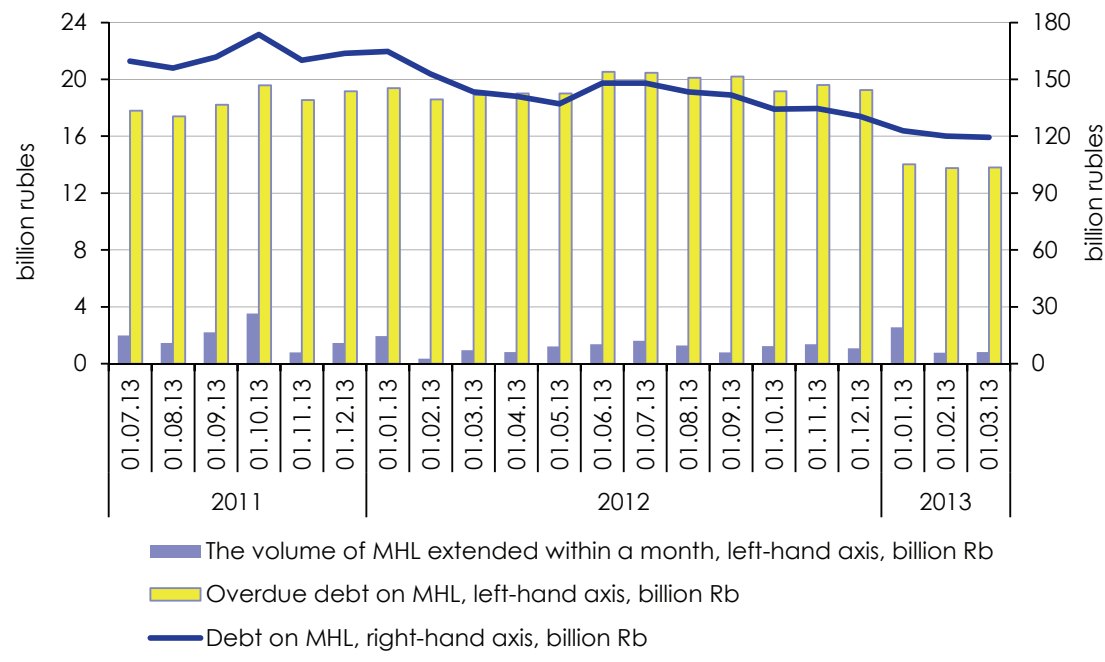

Source: the data of the Central Bank of the Russian Federation.

Fig. 2. Dynamics of MHL and debt on MHL in foreign currency
According to the data of the Central Bank of the Russian Federation, in February 2013 50,281 mortgage housing loans (MHL) for the total amount of $\mathrm{Rb} 80,726 \mathrm{bn}$ and 3,250 unsecured housing loans (UHL) for the amount of $\mathrm{Rb} 2,849 \mathrm{bn}$ were extended. 50,148 MHL in rubles for the amount of Rb 79,911bn and 133 MHL in foreign currency for the amount of $\mathrm{Rb} 0.815 \mathrm{bn}$ were extended (Fig. 1 and Fig. 2). In February 2013, the number of MHL extended in February 2013 exceeded the index of February 2012 by $11.45 \%$ (as regards the volume in monetary terms - by 24.76\%). As of March 1, 2013, the outstanding debt on MHL amounted to $\mathrm{Rb} 2,052.46 \mathrm{bn}$ which is $36.71 \%$ higher than the respective debt as of March 1, 2012. As of March 1, 2013, the debt on MHL in rubles amounted to $\mathrm{Rb} 1,933,056 \mathrm{bn}$ having exceeded by $3.13 \%$ the value of the debt as of January 1, 2013. On the contrary, as of March 1, 2013 the debt on MHL in foreign currency decreased by $2.81 \%$ as compared to the debt on loans in foreign currency as of January 1, 2013 and amounted to Rb 119,404bn. 
As of March 1, 2013, the overdue debt on MHL amounted to Rb 41,846bn, while that on UHL, to $\mathrm{Rb} 5,934 \mathrm{bn}$. As of March 1, 2013, the overdue debt on MHL in rubles amounted to Rb 28,033bn (Fig. 1), which exceeded by $1.82 \%$ the data as of January 1, 2013 (Rb 27,533bn). As of March 1, 2013, the overdue debt on MHL in foreign currency decreased by $1.52 \%$ as compared to January 1, 2013 and amounted to Rb 13,813bn (Fig. 2), while as of March 1 its share in the outstanding debt on mortgage loans in foreign currency increased by 0.15 p.p. as compared to January 1 and amounted to $11.57 \%$.

According to the data of the Central Bank of the Russian Federation, as of March 1, 2013 the volume of the debt on defaulted MHL (with payments overdue for over 180 days) fell to Rb 28.94bn which is $35.88 \%$ lower than that as of January 1, 2013; it is to be noted that the share of that debt in the total amount of the debt on MHL decreased to 1.41\% (Table 1). As of March 1, 2013, the share of the debt without overdue payments fell by 0.2 p.p. as compared to January 1, 2013.

Table 1

GROUPING OF THE DEBT BY MORTGAGE HOUSING LOANS BY THE PERIOD OF DELAY IN PAYMENTS

\begin{tabular}{|c|c|c|c|c|c|c|c|c|c|}
\hline & \multirow{4}{*}{$\begin{array}{c}\text { Total amount } \\
\text { of the debt on } \\
\text { MHL }\end{array}$} & \multicolumn{8}{|c|}{ Including } \\
\hline & & \multirow{2}{*}{\multicolumn{2}{|c|}{$\begin{array}{c}\text { Without } \\
\text { overdue payments }\end{array}$}} & \multicolumn{6}{|c|}{ With overdue payments (days) } \\
\hline & & & & \multicolumn{2}{|c|}{$\begin{array}{l}\text { From 1day } \\
\text { to } 90 \text { days }\end{array}$} & \multicolumn{2}{|c|}{$\begin{array}{l}\text { From } 91 \text { days } \\
\text { to } 180 \text { days }\end{array}$} & \multicolumn{2}{|c|}{ Over 180} \\
\hline & & Million Rb & $\%$ * & Million Rb & $\% *$ & Million Rb & $\% *$ & $\begin{array}{c}\text { Million } \\
\text { Rb }\end{array}$ & $\% *$ \\
\hline \multicolumn{10}{|c|}{2013} \\
\hline Jan. 01 & 1997204 & 1915917 & 95.93 & 30957 & 1.55 & 5193 & 0.26 & 45137 & 2.26 \\
\hline Feb. 01 & 2010552 & 1928321 & 95.91 & 47047 & 2.34 & 5227 & 0.26 & 29957 & 1.49 \\
\hline Mar. 01 & 2052460 & 1964819 & 95.73 & 53159 & 2.59 & 5542 & 0.27 & 28940 & 1.41 \\
\hline
\end{tabular}

* Percentage of the total amount of the debt.

Source: the data of the Central Bank of the Russian Federation.

Growth in the weighted average interest rate on MHL in rubles extended within a month which took place in 2012 - continued in 2013, as well. According to the data of the Central Bank of the Russian Federation, in February 2013 the rate gained 0.1 p.p. and amounted to 12.8\%. As of March 1, 2013, the weighted average rate on loans in foreign currency extended from the beginning of the year amounted to $9.8 \%$ as in 2012 . In January-February 2013, the weighted average rate on loans in rubles refinanced by AHML amounted to $11.38 \%$.

According to the data of the Central Bank of the Russian Federation, in February 2013 the weighted average period of lending as regards MHL in rubles extended within a month amounted to 15.0 years. As of March 1, 2013, the weighted average period of lending as regards loans in foreign currency extended from the beginning of the year increased by 0.94 years as compared to 2012.

In 2012, as regards the number of ruble MHL extended within a year per 1,000 persons the leaders were still the Yamalo-Nenetsk Autonomous Region, the Khanty-Mansiisk Autonomous Region and the Nenetsk Autonomous Region, the Tyumen Region and the Republic of Tatarstan (Table 2). The breakdown by the federal regions remained the same: the leader was still the Urals Federal District, while the North Caucasian Federal District was the last one. Leaders of mortgage lending as regards financial volumes such as St. Petersburg, the Moscow Region, the Central Federal District and Moscow were rated the 59th, the $64 \mathrm{th}$, the $73^{\text {rd }}$ and the $85^{\text {th }}$ as regards the number of mortgage housing loans extended within a year per 1,000 persons, respectively (Table 2).

As in 2011, in 2012 the highest overdue debt as a percentage of the total debt was registered in Moscow (Table 3). In 2012 as compared to 2011, there was a trend of reduction of the overdue debt in the aggregate debt; the above trend was common to all the constituent entities of the Russian Federation. As regards the volume of the early repaid loans as a percentage of the received loans, Moscow was the leader both in 2011 and 2012. The lowest index as regards the volume of funds collected from borrowers as a result of sale of mortgaged property as a percentage of the overdue debt was registered with the North Caucasian Federal District, while the highest one, with the Far Eastern Federal District (Table 3). 
BREAKDOWN OF REGIONS BY THE NUMBER OF MORTGAGE HOUSING LOANS EXTENDED WITHIN A YEAR PER 1,000 PERSONS.

\begin{tabular}{|c|c|c|c|c|c|c|}
\hline \multirow[b]{2}{*}{ Region } & \multicolumn{3}{|c|}{2012} & \multicolumn{3}{|c|}{2011} \\
\hline & $\begin{array}{c}\text { Number of } \\
\text { loans per } \\
1,000 \text { per- } \\
\text { sons }\end{array}$ & $\begin{array}{c}\text { Average } \\
\text { amount } \\
\text { of a loan, } \\
\text { million Rb }\end{array}$ & $\begin{array}{l}\text { Place } \\
\text { in the } \\
\text { rating }\end{array}$ & $\begin{array}{c}\text { Number of } \\
\text { loans per } \\
1,000 \text { per- } \\
\text { sons }\end{array}$ & $\begin{array}{c}\text { Average } \\
\text { amount } \\
\text { of a loan, } \\
\text { million Rb }\end{array}$ & $\begin{array}{l}\text { Place } \\
\text { in the } \\
\text { rating }\end{array}$ \\
\hline $\begin{array}{l}\text { Yamalo-Nenetsk Autonomous } \\
\text { Region }\end{array}$ & 12,208 & 2,188 & 1 & 10,323 & 1,917 & 1 \\
\hline $\begin{array}{l}\text { Khanty-Mansiisk Autonomous } \\
\text { Region }\end{array}$ & 10,721 & 2,097 & 2 & 10,271 & 1,869 & 2 \\
\hline Tyumen Region & 10,384 & 1,917 & 3 & 8,886 & 1,768 & 3 \\
\hline Nenetsk Autonomous Region & 9,068 & 2,052 & 4 & 7,517 & 1,865 & 4 \\
\hline Republic of Tatarstan & 8,546 & 0.943 & 5 & 7,349 & 0.790 & 5 \\
\hline Kirov Region & 8,322 & 0.794 & 6 & 4,836 & 0.843 & 20 \\
\hline Republic of Udmurtia & 8,292 & 0.928 & 7 & 5,171 & 0.943 & 17 \\
\hline Chelyabinsk Region & 7,635 & 1,052 & 8 & 5,811 & 0.936 & 8 \\
\hline Republic of Komi & 7,591 & 1,390 & 9 & 6,101 & 1,073 & 6 \\
\hline URALS FEDERAL DISTRICT & 7,571 & 1,512 & 10 & 5,930 & 1,398 & 7 \\
\hline $\begin{array}{l}\text { PROVOLZHSKY FEDERAL DIS- } \\
\text { TRICT }\end{array}$ & 6,604 & 1,039 & 23 & 4,781 & 0.952 & 21 \\
\hline SIBERIAN FEDERAL DISTRICT & 6,059 & 1,256 & 27 & 4,313 & 1,157 & 28 \\
\hline $\begin{array}{l}\text { FAR EASTERN FEDERAL DIS- } \\
\text { TRICT }\end{array}$ & 5,316 & 1,676 & 38 & 3,958 & 1,474 & 34 \\
\hline RUSSIAN FEDERATION & 5,171 & 1,447 & 41 & 3,660 & 1,369 & 42 \\
\hline $\begin{array}{l}\text { NORTH-WESTERN FEDERAL } \\
\text { DISTRICT }\end{array}$ & 5,052 & 1,679 & 43 & 3,542 & 1,551 & 45 \\
\hline St. Petersburg & 4,500 & 2,336 & 59 & 3,154 & 2,250 & 60 \\
\hline CENTRAL FEDERAL DISTRICT & 4,026 & 2,039 & 73 & 2,786 & 2,002 & 67 \\
\hline $\begin{array}{l}\text { SOUTHERN FEDERAL DIS- } \\
\text { TRICT }\end{array}$ & 3,576 & 1,329 & 79 & 2,534 & 1,292 & 73 \\
\hline $\begin{array}{l}\text { NORTH-CAUCASIAN FEDERAL } \\
\text { DISTRICT }\end{array}$ & 2,873 & 0.957 & 84 & 1,080 & 1,213 & 87 \\
\hline Moscow & 2,868 & 3,741 & 85 & 1,980 & 3,942 & 82 \\
\hline
\end{tabular}

Source: on the basis of Central Bank data of the of the Russian Federation and Rosstat.

According to the data of the Central Bank of the Russian Federation, as of March 1, 2013, the share of the debt on MHL in foreign currency decreased by 0.15 p.p. as compared to February 1 , 2013 and amounted to $5.82 \%$, thus, continuing the trend of reduction of such a share; the above trend prevailed since 2009. The share of MHL in foreign currency in the volume of the extended loans fell by 0.29 p.p. as compared to February 1, 2013 and amounted to $1.20 \%$.

In the $1^{\text {st }}$ quarter of 2013 , AHML refinanced 7,804 mortgages for the amount of $\mathrm{Rb} 11,163 \mathrm{bn}$ which is $10.45 \%$ and $1.9 \%$ lower than the result of the $1^{\text {st }}$ quarter of 2012 as regards the number of loans and in monetary terms, respectively. The share of loans extended under the Maternity Capital program amounted to $9.42 \%$ of the total volume of refinancing in monetary terms with the average amount of a loan being equal to $\mathrm{Rb} 1.47 \mathrm{bn}$, while that of loans extended under the Military Mortgage program, to $31.26 \%$ with the average amount of a loan being equal to $\mathrm{Rb} 2.06 \mathrm{~m}$. In March 2013, the AHML refinanced 2,437 mortgages for the amount of Rb 3.6bn which exceeds the result of February 2013 by $11.9 \%$ and $9.33 \%$ in monetary terms and as regards the number of loans, respectively. In February 2013, the share of loans refinanced by AHML in the total number of mortgage loans amounted to 4.4\%, while in January, to 9.3\%. In March 2013, the average price of housing purchased by means of loans refinanced by the AHML amounted to Rb 44,512 per sq. meter. 
DYNAMICS OF INDICES WHICH CHARACTERIZE BORROWERS OF THE RUSSIAN FEDERATION

\begin{tabular}{|c|c|c|c|c|c|c|}
\hline \multirow[t]{2}{*}{ Region } & \multicolumn{2}{|c|}{$\begin{array}{c}\text { The overdue debt } \\
\text { as } \% \text { of the total } \\
\text { debt }\end{array}$} & \multicolumn{2}{|c|}{$\begin{array}{c}\text { The volume of MHL } \\
\text { which was early repaid } \\
\text { within a year by means } \\
\text { of borrower's funds as } \\
\% \text { of the volume of the } \\
\text { received MHL }\end{array}$} & \multicolumn{2}{|c|}{$\begin{array}{l}\text { The volume of funds } \\
\text { collected from borrowers } \\
\text { as a result of sale of } \\
\text { mortgaged property } \\
\text { as } \% \text { of the overdue debt }\end{array}$} \\
\hline & 2012 & 2011 & 2012 & 2011 & 2012 & 2011 \\
\hline Moscow & 5.11 & 6.42 & 36.09 & 37.68 & 9.24 & 6.91 \\
\hline Moscow Region & 4.65 & 5.84 & 25.84 & 27.72 & 5.72 & 4.98 \\
\hline CENTRAL FEDERAL DISTRICT & 3.71 & 4.93 & 25.62 & 29.76 & 7.82 & 6.36 \\
\hline $\begin{array}{l}\text { NORTH CAUCASIAN FEDERAL } \\
\text { DISTRICT }\end{array}$ & 2.58 & 4.06 & 14.62 & 16.42 & 3.33 & 5.54 \\
\hline St. Petersburg & 2.17 & 2.96 & 27.91 & 25.43 & 18.34 & 14.92 \\
\hline RUSSSIAN FEDERATION & 2.10 & 3.06 & 21.10 & 24.32 & 10.15 & 9.95 \\
\hline $\begin{array}{l}\text { SOUTHERN FEDERAL DIS- } \\
\text { TRICT }\end{array}$ & 1.83 & 2.70 & 15.65 & 19.61 & 4.96 & 7.53 \\
\hline $\begin{array}{l}\text { NORTH-WESTERN FEDERAL } \\
\text { DISTRICT }\end{array}$ & 1.68 & 2.51 & 21.84 & 19.80 & 15.89 & 12.07 \\
\hline SIBERIAN FEDERAL DISTRICT & 1.62 & 2.63 & 20.28 & 23.40 & 11.40 & 12.21 \\
\hline $\begin{array}{l}\text { PRIVOLZHSKY FEDERAL DIS- } \\
\text { TRICT }\end{array}$ & 1.41 & 2.28 & 16.92 & 20.64 & 14.74 & 19.72 \\
\hline URALS FEDERAL DISTRICT & 1.04 & 1.53 & 21.89 & 27.43 & 14.81 & 12.94 \\
\hline $\begin{array}{l}\text { FAR EASTERN FEDERAL DIS- } \\
\text { TRICT }\end{array}$ & 0.56 & 1.11 & 19.05 & 17.62 & 20.55 & 15.38 \\
\hline
\end{tabular}

Source: on the basis of the data of the Central Bank of the Russian Federation.

In accordance with the AHML's program of October 2012 related to purchasing of senior tranches of mortgage-backed bonds, as of April 1, 2013 the AHML concluded contracts on repurchasing of $\mathrm{Rb} 45,675 \mathrm{bn}$ worth of such bonds. In 2013, the volume of repurchased mortgage securities amounted to Rb 0.83bn. Also, as of April 1, 2013, the Agency provided market participants with special-purpose loans for accumulation of mortgage backing and finalizing of a securitization deal for the amount of $\mathrm{Rb} 13.94 \mathrm{bn}$; the current debt under the above deal amounts to Rb 10.04bn.

A draft law on amendment of the Law on Mortgage (Mortgage Security) was submitted to the State Duma. The above draft law provides for repurchasing in certain cases of mortgaged housing of an insolvent borrower and provision of that housing to the borrower on the terms of a social loan with the right of repurchasing it in future. 